\title{
ADVANCEMENTS IN GRASSLAND FARMING IN TARANAKI
}

By C. J. HAMBLYN, Fields Superintendent, Department of Agriculture, Palmerston North.

In presenting some of the outstanding advances which have been made in grassland farming in the Province of Taranaki, a somewhat artificial subdivision of the subject seems advisable.

Advances and improvements have been made in methods of pasture establishment resulting in better pastures generally. The maintenance and improvement of pastures in Taranaki have presented special problems which are being dealt with by her grassland farmers, and good utilisation and management of pastures has been a feature of farming in the province. While the sum total of the efforts of the farmers of the province is developing better grassland farming is reflected in increased production of butterfat, meat and wool there is still plenty of scope for further development of the productive capacity of the grasslands of the area. It is proposed to review under the separate headings of pasture establishment,. pasture maintenance and improvement, and pasture management and utilisation, the progress made.

Because the soils and topography of the volcanic lands surrounding Mount Egmont, which have been developed in the main for dairying, are so different from. the deeply dissected, steep, and rugged sandstone, mudstone, and papa soils of the vast hinterland area, it is necessary to deal with these two main subdivisions separately.

\section{PASTURE ESTABLISHMENT}

Volcanic Lands. With the exception of a narrow fringe of open country along the sea coast, the volcanic land presented to the early settlers a dense and almost impassable cover of heavy rain forest with giant puriri near the coast, rimu and rata further inland, as the top canopy, and kohe-kohe, tawa, matai, maire, and pukatea the main subspecies, the whole inter- 
twined with dense brakes of supplejack, bush'-lawyer and other creepers with a ground covering of ferns of many varieties.

The coastal fringe was covered with dense bracken fern where Maori clearings had removed the general cover of shrubby mahoe, karaka, titoki, etc.

In the establishment of grasslands on the volcanic soils the whole of this cover including the $\log s$ and stumps has been completely removed by hand and fire and the ploughable land has been turned over many times in the course of growing crops and establishing pastures. Much of the land from Inglewood to Stratford and beyond has been felled and cleared in the past 50 to 70 years. While the open fringe country had to be used extensively in the first 10 to 20 years of settlement mainly for the production of grain crops for food it was early found that wheat, oats, and barley seed roughly scratched into the surface ash of bush-burn fires amongst the logs and stumps gave heavier yields and better crops than those obtained from the partially worn out bracken' fern and light scrub land. Bush burns were often therefore used to grow such crops until these could be 'imported. Amongst the first exported products of grassland resulting from the sowing of grass and clover seeds on the bush burns was grass seed, mainly cock'sfoot. In this connection it is interesting to note that where seed production was intended some 6 to $121 \mathrm{~b}$. of cocksfoot seed per acre was sown. In the first year the crop was almost smothered with weeds, but the clumps of cocksfoot so 'established asserted themselves in the next year giving a dense stand of cocksfoot which when in full seed head could be tied across the'withers of a horse. Such stands were cut for several years for seed, eventually giving way to a weedy open pasture among the rotting logs and stumps. In the cleaning up process log and stump fires repeatedly swept over the country, necessitating much reseeding. Details of grass seed mixtures used in the establishing of pastures on both ploughed land and on the bush burns of the volcanic country show that English grasses, including cocksfoot, perennial rye, timothy, meadow foxtail, meadow fescue, Poa trivialis, and Poa

pratensis, were used, together with such clovers as white, red, suckling, and alsike. About 2 bushels of seed per a\&e seems to have been a standard seeding. The initial fertility resulting from the ash of the bush fires and the second burns of logs and stumps was soon lost to the soil, being removed in produce, washed 
from the surface, or leached through the soil as a result of the heavy rainfall. Pastures deteriorated rapidly, with plantain, or ribgrass, catsear, dandelion, field daisy, pennyroyal, docks, and all manner of other weeds taking the place of the grasses.

In order to renew the pastures the land had to be ploughed, but before this could be done the logs and stumps that littered the ground had to be removed and burnt. A slow and laborious process, but with few exceptions. it can be claimed that almost every acre of present day grassland on this volcanic country has . been cleared by hand, ploughed if not too steep, and pastures renewed not once but several times, generally after cropping. Unfortunately this process of pasture renewal had been completed in the main, particularly on the older settled areas, some years before the introduction of the improved strains of grasses and clovers 'through certification, and a policy of all-grass farming was being developed about the time that seed certification started.

Cropping, which occupied between 25;000 and 30,000 acres from 1920 to 1928 had dropped to 15,000 by $1935-40$ and 13,000 acres in 1948-49. During this period of reduced cropping a much smaller area has been sown to new grass each year and only a relatively small portion of the total ploughable grasslands of the province has therefore been renewed with the better strains of grasses and clovers; on more and more farms from the early 1920's on, the plough was discarded in favour of the grass harrows and the mower, which, together with topdressing, were relied on in an all-grass farming policy for the maintenance of the pastures.

One of the major reasons often given by Taranaki farmers for not breaking up old turfs has been the difficulty in getting a good and quick establishment of better species after ploughing. This difficulty has been most pronounced on the lighter and poorer volcanic soils, particularly after more than one crop has been taken from the land.

The, roller is an essential implement on Taranaki farms in the establishment of better pastures, though the use of the roller can be avoided by a long and careful preparation of the seed bed, allowing time and the weather to effect consolidation. More and more Taranaki farmers realise the importance of consolidation and also the fact that cropping, though necessary and profitable at times, loosens the soil to the extent 
that after crops the roller is even more important than it is where new pastures are established straight after grass. An 'increasing number of Taranaki farmers are using the direct-from-old-grass-to-new-grass method, of pasture establishment which has been very successfully demonstrated at the Manaia Demonstration Farm for some years. Even where this method is used the use of the roller first on the plough furrow and later on the disced land is a great aid in getting good establishment especially of the clovers.

In recent years probably the most important development in pasture establishment on these volcanic soils has been in the matter of grass-seed mixtures. ' The introduction of more and more short-rotation ryegrass and the adoption of management methods best suited to this species and the maintenance of fertility conditions required by it to give the production it is capable of may prove to be another milestone in Taranaki grassland development..

At the present time, while there are strong advocates of the value of short-rotation ryegrass on the dairy lands of the province and there are some excellent demonstrations on a farm scale of its successful introduction and exploitation, there are many farmers whose preliminary experience has caused them to condemn this type of ryegrass.

There is no doubt that Taranaki has the climate for short-rotation ryegrass, it has, over much of the area, suitable soils and soil fertility, and the pasture management and utilisation methods are very suited to its requirements. Short-rotation, given a fair chance, should do well. over much of the dairying land in the district and should fill a long-felt want. in pro-" viding more and better winter and early-spring feed.

The Hill Country: Turning now to the hinterland hill country the story here has not been one of successful progress as far as pasture establishment is concerned except on that considerable area of borderland where the two types meet and to some extent intermingle. This belt of borderland has indeed been developed on much the same lines as the volcanic land except that the unploughable land has had to be surface sown after bush and secondary burns and hand topdressed, This is largely the fat-lamb-producing area of Taranaki and progress on this country has been demonstrated in the increased numbers of fat lambs coming forward for killing each year. 
The real hinterland country inland from Waitara, Urenui, Uruti, T'ongaporutu, and Mokau on the coast and not many miles inland from Tarata, Toko, Eltham, and Patea, was not taken up until 1890 and later, and much of it was taken up in the early 1900's. This country is steep and rugged and was heavily timbered, the soils varying from poor sandstone to mudstone with papa pockets and patches. The valleys were narrow and the country rose ridge on ridge from a few hundred feet up to 2000 feet in places. The rainfall is high, 70 to 80in. over most of it. Here, as the surveys were completed, blocks were opened up mostly as crown land in relatively small sections and the settlers, mainly with little money and often less experience, went in to carve out homes and a living for themselves. Much the same methods were used in felling the bush, seeding the burns, and so on as were applied to'the volcanic lands but on this steep, high-rainfall country the English grasses and clovers which were sown soon gave way to second growth of various kinds-to water fern, wineberry, fuchsia, and tutu in the first place and, where these were cleared and reburnt, to bracken fern, hard fern, hutuwai, and eventually to manuka.

Settlement in many places preceded roads, access to homesteads being by bridle track or rough-formed mud roads. Many thousands of acres of country that was felled and sown has been abandoned and many thousands of acres of bushland that was taken up is still in virgin bush.

There is, of course, still considerable settlement round Whangamomona and Tahora, with other cleared and farmed areas round Ohura and on a few other isolated and scattered areas through this country. Such cleared land is mainly based on wide valleys where dairying has been possible or the occupiers had a sufficient area of the better papa country, which, despite slipping, has maintained grass.

A combination of adverse factors contributed to the failure of successful large-scale settlement of this country, among the main ones which may be mentioned being the high rainfall, which produced rapid regeneration of many types of second growth and prevented in many cases good clean burns, the lack of capital, and in many cases of experience, of the early settlers, the poor roads and often lack of roads, and the further fact that English grasses and clovers were used, such species as browntop, danthonia, Lotus 
major and suckling clover being left out of the original bush burn and second growth sowings.

Extensive experimental and demonstration work carried out by Messrs E. Bruce Levy and E.. A. Madden in the late 1920's showed that these species were essential to grassing this country successfully and that with their use satisfactory swards of good production could be established and maintained, not only on the better papa and mudistone soils but also on most of the sandstone country. This knowledge came however, somewhat too late to save the majority of the holdings in the. real hinterland, but it has been used with considerable success by many settlers, particularly by those who are again invading this country from the outside or from established farmlands in the wider valleys.

Pasture Maintenance and Improvement : Volcanic Soils : The scene on the Volcanic soils of Taranaki today -clean fields, neat hedges, tree planted gullies and extensive shelter belts-does not give much indication of the battle which has been fought and which is in 'many places still being fought, particularly in North and Central Taranaki, to maintain the grasslands of the province in the condition in which we find them.

In the $\log$ and stump days pastures had deteriorated and the term "full of flat weeds," meaning dandelion, ribgrass, catsear, hawk-bit, and field daisy, was common in describing deteriorated pastures. Bracken fern invaded the land long before stumps could be easily removed and the dairy cow did not relish having to deal with this invader, so it had to be cleared by the plough, the mower, or by hand. Then blackberry, imported as a hedge plant and gorse, also used in hedges and in places as fodder in the early days, escaped from farm lands and found the conditions of a loose, light soil, high rainfall, and plenty of rotting $\operatorname{logs}$ and stumps ideal for rapid spread.

In South Taranaki, though this country could grow bracken, gorse, and blackberry as well as any, the problem of the maintenance of clean pastures in the face of these weeds has never been a really difficult one. This is due to the much greater proportion of ploughable land, the generally more fertile soils, and also to the fact that gorse and blackberry were not established in the early days as hedges.

Ragwort is another weed which has given a great deal of trouble throughout Taranaki, but especially in 
the North where it was first introduced and was well established when most of the country was in logs and stumps. For many years a ceaseless battle against this invader was waged by the settlers, their only method of control being hand pulling the plants when in full flower. Where ragwort got out of hand later, spraying with sodium chlorate and dusting was used effectively in its control. The battle with ragwort still goes on, the new hormone sprays having largely. replaced sodium chlorate.

Mineral deficiencies in the volcanic soils resulting in rapid deterioration of pastures very soon became apparent, and of these the lack of phosphate has been outstanding. As early as 1885 bonedust was being imported to correct phosphate deficiency, which developed first in North Taranaki and later throughout the province. By the early 1900's considerable quantities of bonedust, basic slag, and imported superphosphate were being used and phosphatic topdressing has developed into one of the essential and major features of pasture maintenance. On some of the older farmed areas potash deficiencies had also developed by the early 1900's and up to the outbreak of the 1914-18 war increasing quantities of kainit, a low-grade potash fertiliser, were being applied. Since the Second World War the need for potash has been shown to be much more general than at any previous period.

\section{PASTURE MANAGEMENT AND UTILISATION}

It is in the development of efficient pasture management and utilisation rather than in the exploitation of better species of grasses and clovers that Taranaki grassland farmers have demonstrated their skill and ability.' From 1925, when the idea of intensive grassland utilisation through smaller paddocks and rotational grazing was first introduced to this country, Taranaki farmers were quick to adopt the new methods and an era of all-grass farming over a large proportion of the volcanic lands was developed. In a matter of some 10 to 12 years some of the leading dairy farmers, with nothing like the best of conditions of soils, pastures, or layout to begin with had, by the adoption of rotational grazing, the conservation of surplus grass as silage and hay, and the introduction of saving of autimn grass for spring feed, achieved outstanding butterfat production per acre. One outstanding fảrm among many had reached in 1937 the then remarkable production figures of $18,360 \mathrm{lb}$. of butterfat from 50 
acres of grass-some 3671b. ,per acre, with all stock wintered on the farm. There were a number of others with production figures well over 3001b. per acre.

These farmers had put into operation systematic grazing management and full utilisation of the grass grown.

It is interesting to note that almost without exception silage has been the sheet anchor in the provision of supplementary feed on all farms which have achieved really high butterfat production per acre.

Taranaki farmers were early in the field in the adoption of the electric fence as an aid to better pasture utilisation and the closing of up to $1 / 3$ of the farm in the late autumn for the provision of grass for the early spring is also a general procedure.

The latest development in grassland farming is the exploitation of short-rotation ryegrass and, particularly in South Taranaki, where the summers are much drier, of Montgomery red clover for the better provision of winter and early spring feed on the one hand and more and better greenfeed in the late summer on the other.

Reverting once again to that vast hinterland of hill country it does appear that with the advent of the aeroplane and the possibility of applying fertiliser and seed much more easily to this country than has been the case in the past, for some parts of it at least, the future is somewhat brighter than at first appears. There are still pioneers throughout the: area achieving remarkable results by better stock management and the use of more cattle together with the use of pasture species more suited to the conditions. There is proceeding a steady penetration of the area from the outside by a process of clearing of scrub, burning, resowing and fencing, together with better stocking and topdressing, the results of which are demonstrating that this country can grow and maintain grass. How long and how far this process of development will have to proceed before confidence in the possibilities of this country as grassland is restored sufficiently for resettlement to be taken up in earnest again is a matter of conjecture. Suffice it to say that this huge block of several millions of acres of country presents to the grassland men of New Zealand one of the outstanding' problems of the country. 
DISCUSSION

Q. What changes have taken place in seeding rates on ploughable land in Taranaki?

A. Very little real change in rates, but there has been considerable change in species sown and in the mixtures used.

$\mathrm{Q}$. What time lapse is there between bush burn and the encroachment of manuka in Taranaki and why ?

A. Varies with development method followed. Manuka usually comes in, when it does, after about 15 years, but before this there is usually a battle with other forms of secondary growth.

Mr Levy commented that he agreed with the time of 15 'years, for the first manuka invasion. This usually follows bracken fern, and is usually accompanied by hard fern and/or piri-piri, all these latter invaders liking the light and being able to stand up to the conditions of hard continuous grazing. Quite a lot of the weed invasion followed the lack of browntop and danthonia in the original sowings. These species form a tight sward and prevent a lot of the weeds getting going.

- Q. . Would 'you be worried. about ratstaii coming' in to a pasture?

A. Yes I would, but cannot give satisfactory over-al! control methods. 